\title{
KOGNITYWNY MODEL ANALIZY TEKSTU W DYDAKTYCE PRZEKŁADU PISEMNEGO - KSZTAŁCENIE KREATYWNEGO ROZUMIENIA U POCZĄTKUJĄCYCH TŁUMACZY
}

DOl: http://dx.doi.org/10.12775/RP.2016.010

Zarys treści: Autorka podejmuje próbę zastosowania kognitywnej teorii języka w dydaktyce przekładu i pokazuje, jak kształcić kluczową dla procesu translacji umiejętność kreatywnego rozumienia. W tym celu przedstawia na podstawie założeń gramatyki kognitywnej Langackera uproszczony model analizy tekstu pod kątem przekładu, przeprowadza przykładową analizę niemieckiego tekstu prasowego i wykazuje także przydatność tego modelu na etapie analizy i oceny rozwiązań translatorskich proponowanych przez początkujących tłumaczy. Kontrastowanie w analizie rozwiązań błędnych, akceptowalnych i bardzo dobrych kładzie nacisk na analizę procesu tłumaczenia i wprowadza element autorefleksji do przekładu.

Słowa kluczowe: kognitywny model analizy tekstu, kreatywne rozumienie, przekład pisemny, błędy tłumaczeniowe, autorefleksja

\section{Kognitywna teoria języka a dydaktyka przekładu}

edną z pierwszych prób zastosowania koncepcji badawczych wywodzących

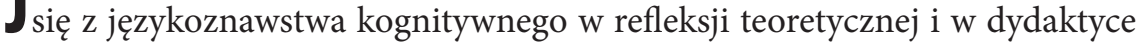
przekładu pisemnego na gruncie polskim jest kognitywno-komunikacyjna teoria przekładu (Hejwowski 2004). Bazując na takich założeniach jak semantyka ram i scen (Fillmore 1977, Schank 1982a), koncepcja scenariuszy (Schank, Abelson 1977, Schank 1982a, 1982b), a także na zasadzie współ- 
działania i implikatury konwersacyjnej (Grice 1975) oraz kognitywnej teorii metafory (Lakoff, Johnson 1980, Lakoff, Turner 1989) - by wymienić najważniejsze z wykorzystanych w tej pracy teorii - autor dokonuje kompleksowego opisu procesów komunikacji i przekładu, proponuje model analizy tekstu pod kątem przekładu oraz przedstawia szczegółową typologię błędów popełnianych przez początkujących tłumaczy, odwołując się do tłumaczonych przez nich tekstów ${ }^{1}$. Stosunkowo wcześnie interesujące próby zastosowania paradygmatu kognitywnego w analizie przekładu zostały także podjęte na gruncie germanistycznym. Przegląd dotychczasowych badań w tym zakresie pozwala wyróżnić prace koncentrujące się na zastosowaniu określonej koncepcji badawczej w przekładzie, np. semantyki ram i scen (Snell-Hornby, Vannerem 1986, Vermeer, Witte 1990), lub gramatyki kognitywnej Langackera w rozważaniach nad konceptem jako podstawową jednostką sensu w tłumaczeniu (Kubaszczyk 2000) oraz bardziej złożone modele, wykorzystujące wiele teorii do opisu procesu przekładu.

Przykładem takiego modelu jest model Kussmaula (1997, 2007), który kładzie nacisk na analizę „kreatywnego myślenia językowego” jako kluczowej umiejętności każdego tłumacza. W tym celu autor odwołuje się zarówno do psychologicznych modeli kreatywnego myślenia (de Bono 1971), jak i do teorii wypracowanych w ramach językoznawstwa kognitywnego, w tym do gramatyki kognitywnej Langackera (perspektywa, układ figura-tło), semantyki prototypu, semantyki ram i scen (Fillmore 1977) oraz do koncepcji łańcucha powiązań (Lakoff 1987). Nowość tego podejścia polega na analizie tłumaczenia jako produktu na przykładzie tekstów prasowych i literackich jak i na analizie procesu decyzyjnego początkujących tłumaczy. Autor wyróżnia siedem typów (technik) kreatywnego przekładu². Zarówno Kussmaul (2007), jak i Grucza (1999) zwracają uwagę na fakt, że praca translatora wymaga podwójnej kreatywności i dotyczy rozumienia cudzych wyrażeń/tekstów i oddawania ich znaczenia w innym języku. O ile czytanie i rozumienie implikuje operacje o charakterze (od)twórczo-kreatywnym mające na celu rekonstrukcję sensu tekstu wyjściowego, to kreatywność tłumacza na płaszczyźnie językowej polega na dokonaniu twórczego wyboru ze środków istniejących lub w przypadku braku adekwatnego ekwiwalentu w języku docelowym na stworzeniu odpowiednika względnie adaptacji wyrażenia obcego. Najnowsze badania koncentrują się w związku z tym nie tylko na kompetencjach językowych, ale i niejęzykowych tłumacza, w tym na opisie rodzajów wiedzy tłuma-

${ }^{1}$ Bibliografia prac za: Hejwowski (2004: 49).

${ }^{2}$ Bibliografia prac za: Kussmaul (2007: 81-122). 
cza i analizie operacji kognitywnych aktywizowanych w procesie rozumienia tekstu wyjściowego i tworzenia tekstu docelowego. Porównanie kompetencji translacyjnej profesjonalnych tłumaczy i studentów wskazuje, że niewystarczająco rozwinięta kreatywność, brak płynności asocjacyjnej, ograniczona wrażliwości poznawcza, językowa i interkulturowa w znaczący sposób wpływają na efektywność działań translacyjnych (Małgorzewicz 2012, 2013, 2014, Żmudzki 2013).

W kontekście przeprowadzonych badań powstaje więc pytanie, która z prezentowanych koncepcji badawczych może stać się skutecznym i najbardziej przystępnym narzędziem w kształceniu umiejętności kreatywnego rozumienia dla celów przekładu nie tylko z punktu widzenia tłumacza-nauczyciela, ale także z punktu widzenia uczącego się.

W niniejszym artykule chciałabym dowieść, że obie te funkcje $\mathrm{w}$ dydaktyce przekładu pisemnego może z powodzeniem spełnić jedna teoria - gramatyka kognitywna Langackera. W tym celu chciałabym przedstawić uproszczony model analizy tekstu pod kątem przekładu, który może pomóc tłumaczom w rozwijaniu umiejętności wnikliwego i kreatywnego rozumienia, a także wykazać przydatność tego modelu również na etapie analizy rozwiązań translatorskich i omówienia częstych błędów semantycznych popełnianych przez początkujących tłumaczy. Na materiał analizy składają się tekst prasowy pt. Grauer Markt („Der Spiegel” 2006, nr 32) i jego przekłady na język polski wykonane przez studentów studiów II stopnia filologii germańskiej.

\section{Kognitywny model analizy tekstu w dydaktyce przekładu}

Punktem wyjścia dla rozważań na temat przekładu, zadań tłumacza i proponowanego modelu analizy tekstu pod kątem przekładu jest dynamiczna i encyklopedyczna koncepcja znaczenia w ujęciu Langackera $(2005,2009)$, zgodnie z którą znaczenie jest tożsame z konceptualizacją, a więc jest każdorazowo konstruowane $\mathrm{w}$ umyśle konceptualizatora na potrzeby danej sytuacji komunikacyjnej i w interakcji z innymi uczestnikami dyskursu. Langacker, w odróżnieniu od innych badaczy, kładzie nacisk nie tylko na uwzględnienie treści pojęciowych, ale także na sposób ich przedstawiania przez mówiącego-konceptualizatrora, określany również jako konwencjonalne obrazowanie lub konstruowanie sceny. Do parametrów konstrukcji sceny zalicza m.in. poziom uszczegółowienia konceptualizacji, poziom wyróżnienia (profilowanie, układ figura-tło) oraz perspektywę. 
Przyjęcie takiej koncepcji znaczenia w przekładzie oznacza, że główne zadanie tłumacza jako pierwszego odbiorcy tekstu polega na rekonceptualizacji/rekonstrukcji treści tekstu wyjściowego, określeniu zakresu rozumienia tekstu przez odbiorców tekstu wyjściowego, a następnie na rekonstrukcji tych treści dla odbiorcy w tekście docelowym. Przebieg tłumaczenia jako operacji mentalnej szczegółowo wyjaśnia Kubaszczyk (2000: 81):

Tłumaczenie polega więc na zastąpieniu pojęcia wyrażonego w języku wyjściowym identycznym lub maksymalnie podobnym pod względem znaczeniowym konstruktem w języku docelowym. Jest to możliwe przez nałożenie na treści kognitywne leżące u podstaw pojęcia w języku wyjściowym schematów organizacji treści języka docelowego, przy czym należy dążyć do zachowania identyczności lub maksymalnego podobieństwa pojęć. (por. Kubaszczyk 2000: 81, tłum. M.F.)

Ekwiwalencja w takim ujęciu jest więc ekwiwalencją na poziomie interpretacji tekstu w umysłach odbiorców oryginału i przekładu (Hejwowski 2004), a także bardziej szczegółowo - ekwiwalencją na poziomie obrazowania (Tabakowska 2001, Kubaszczyk 2000). Podstawową jednostką do tłumaczenia jest natomiast jednostka tekstu odpowiadająca scenie lub pojęciu, w tym zarówno pojęciu szczegółowemu, jak i złożonemu (Kubaszczyk 2000).

Mając na uwadze powyższe założenia wynikające z kognitywnej koncepcji znaczenia i gramatyki $\mathrm{w}$ ujęciu Langackera oraz ich zastosowanie w rozważaniach nad procesem translacji, ekwiwalencją i jednostką tłumaczeniową, chciałabym zaproponować uproszczony model analizy tekstu pod kątem przekładu, który mógłby znaleźć zastosowanie w dydaktyce przekładu, zwłaszcza na etapie początkowym rozwijania kompetencji tłumaczeniowych. Na proponowany model składają się trzy fazy analizy tekstu wyjściowego, które określam jako: 1) konceptualizacja jako proces wyróżniania pojęć, 2) kontekstualizacja, 3) obrazowanie.

Pierwsza faza analizy tekstu polega na zaproponowanym przez $\mathrm{Ku}-$ baszczyk (2000) wyróżnianiu konceptów jako podstawowych jednostek treści zarówno w tekście, jak i w przekładzie, a nie na koncentrowaniu się wyłącznie na określonych formach językowych. Za autorką przyjmuję również podział na pojęcie globalne (odpowiadające treści całego tekstu) i pojęcia szczegółowe, a także wynikającą z tego podziału główną strategię tłumaczeniową polegającą na tłumaczeniu w pierwszym rzędzie pojęć złożonych, a następnie szczegółowych. Przyjęcie w przekładzie podejścia zorientowanego na wyróżnianie jednostek konceptualnych kładzie nacisk na przekaz treści i tym samym pomaga zapobiegać błędom dosłowności, wy- 
nikającym z tłumaczenia linearnego słów, zdań oraz z homonimii wyrażeń językowych.

Druga faza analizy tekstu wynika z założeń semantyki encyklopedycznej i koncentruje się na analizie jednostek treściowych w ścisłym powiązaniu $\mathrm{z}$ kontekstem pragmatycznym. Zgodnie $\mathrm{z}$ nimi znaczenie leksykalne wyrażenia nie jest całkowicie ustalone, ani całkowicie dowolne i jest zależne od wiedzy encyklopedycznej konceptualizatora, która stale się zmienia. Dane słowo reprezentuje konwencjonalny sposób dostępu do zbioru domen kognitywnych. Dla określenia wartości semantycznej słowa pewne domeny pełnią funkcję domen centralnych, a inne funkcję domen peryferyjnych. To, które $\mathrm{z}$ domen pełnią funkcję domen centralnych, a które z nich są domenami peryferyjnymi, jest uwarunkowane kontekstowo. W tym sensie dana jednostka leksykalna może więc mieć wiele nowych znaczeń. Ilustracją tego procesu może być wyrażenie Grauer Markt, które w swoim podstawowym znaczeniu oznacza szary rynek, a w analizowanym w dalszej części artykułu tekście występuje w zupełnie nowym znaczeniu i odnosi się od seniorów na rynku pracy. Nowe znaczenie wyrażenia powoduje więc aktywowanie innych domen jako centralnych i tym samym przesunięcie „do tła” domen aktywowanych dla znaczenia konwencjonalnego. Powyższe założenie dotyczące roli kontekstu w kształtowaniu i interpretacji znaczenia jest szczególnie ważne w kontekście dydaktyki przekładu i pozwala zrozumieć, dlaczego ekwiwalent słownikowy nie zawsze może pełnić funkcję ekwiwalentu tłumaczeniowego. Ekwiwalent tłumaczeniowy, by uwypuklić istotne dla danego komunikatu aspekty znaczenia i spełnić swoją funkcję komunikacyjną w przekładzie, musi być dostosowany kontekstualnie.

Ostatnia faza analizy tekstu dotyczy sposobu konstrukcji jednostek konceptualnych. Wśród parametrów konstrukcji sceny szczególną funkcję pełni perspektywa, rozumiana zarówno jako perspektywa interpretacyjna, jak i w węższym zakresie jako perspektywa oglądu. Celem analizy jest określenie punktu widzenia autora tekstu wyjściowego i założeń, jakie czyni on w stosunku do wiedzy swojego odbiorcy, a następnie ustalenie, za pomocą jakich środków językowych perspektywa ta może zostać oddana również w tekście docelowym.

\section{Analiza kognitywna tekstu prasowego pod kątem przekładu}

W proponowanej analizie tekstu pod kątem przekładu bazuję na wprowadzonym przez Kubaszczyk (2000: 81) rozróżnieniu pojęcia globalnego i pojęć 
bardziej szczegółowych. Celem wyróżnienia pojęcia globalnego jest rekonstrukcja ogólnego sensu tekstu, rekonstrukcja perspektywy interpretacyjnej nadawcy tekstu (punkt widzenia nadawcy, w tym również emocjonalny punkt widzenia), określenie perspektywy interpretacyjnej odbiorców (zakres rozumienia tekstu wyjściowego) oraz określenie dziedziny, z której tekst pochodzi. Celem wyróżnienia pojęć częściowych jest z kolei określenie treści szczególnie istotnych z punktu widzenia semantyki tekstu i mogących powodować trudności w jego rozumieniu. Analiza na tym etapie obejmuje ustalenie rodzaju znaczenia (konwencjonalne, niekonwencjonalne), określenie treści pojęciowych i relacji semantycznych między nimi, a także określenie domen centralnych aktywowanych przez dane wyrażenie i analizę kontekstu, w jakim wyrażenie zostało użyte. Następnym krokiem jest określenie sposobu obrazowania ${ }^{3}$.

Na podstawie tego modelu przeanalizujmy następujący fragment tekstu („Der Spiegel” 2006, nr 32):

\section{Grauer Markt}

Dass ihnen ausgerechnet ein Rentner aus der Patsche helfen würde, damit hatten die Pietschmanns nun wirklich nicht gerechnet. Kurz vor Weihnachten hatte ihre Lüftungsfirma Außenstände von 250000 Euro aufgetürmt - und die Hausbank kündigte das Konto. 15 Mitarbeiter bangten um ihren Job. „Wir standen vor der Pleite und haben mit dem Schlimmsten gerechnet", sagt Juniorchef Georg Pietschmann, „bis uns ein Freund den Rat gab: 'Geht doch zum SES.“

Der Senior Experten Service (SES) in Bonn schickt Fachkräfte im Ruhestand als ehrenamtliche Entwicklungshelfer rund um den Erdball - und seit geraumer Zeit vermehrt in ein nahe liegendes Krisengebiet: den deutschen Mittelstand. Firmen in Not erhalten kostenlose Sofortberatung von einem der etwa 7200 registrierten Senior-Experten. Bloß Spesen und Bearbeitungsgebühren müssen die Unternehmen bezahlen.

Zu den Pietschmanns im sächsischen Ebersbach fuhr Hans-Reinhard Wimmeroth, 61, der jahrzehntelang ein Baugeschäft geführt hatte. Mit Josef Pietschmann, 62, und dessen Sohn Georg, 29, studierte er den Pleitefall. Unterstützt von zwei weiteren SES-Männern, einem Ex-Wirtschaftsprüfer und einem Anwalt a. D., half er beim Ausfüllen von Formularen, suchte den Kontakt zum Insolvenzverwalter, beschwor die Banken und telefonierte mit Auftraggebern. Wie im TV-Hit „Der gro-

${ }^{3} \mathrm{~W}$ analizie odwołuję się także do często stosowanego przez początkujących tłumaczy polsko-niemieckiego słownika internetowego PONS, by wykazać, skąd biorą się ich trudności i pewne ograniczenia interpretacyjne. 
ße Bellheim“ waren es graue Stars, die das Unternehmen schließlich retteten. „Im Kern war die Firma gesund, es fehlte nur etwas unternehmerisches Knowhow“, sagt Wimmeroth. Die guten Kunden und alle Mitarbeiter wurden schließlich von einer Nachfolgefirma in Familienbesitz übernommen - das 1875 gegründete Geschäft war gerettet.

Solche Rentner-Einsätze machen Schule: Quer durch die Republik vermitteln Gesellschaften und Vereine mittlerweile Fachkräfte im Ruhestand als Berater. Der Gründer Support Ruhr aus Essen beispielsweise stellt jungen Firmengründern erfahrene Ex-Unternehmer zur Seite. Etliche regionale Wirtschaftssenioren- und Alt-hilft-Jung-Vereine unterstützen Start-up- und Problemfirmen.

Auch Konzerne nutzen immer häufiger das Rentner-Wissen. Bosch, Siemens oder der deutsche Ableger des Pharmakonzerns Pfizer etwa engagieren ihre eigenen Ex-Mitarbeiter für dann allerdings gutbezahlte Kurzeinsätze. „Der Prozess des Umdenkens ist in vollem Gange“, sagt Hans Böhm, Geschäftsführer der Deutschen Gesellschaft für Personalführung. Immer mehr Personalchefs würden erkennen, dass mit Rentner-Einsätzen vorhandenes Know-how rasch, günstig und vor allem flexibel eingekauft werden könne. Zudem kenne oft niemand die Bedürfnisse einer Firma besser als die Ex-Mitarbeiter. Mit Nachwuchsproblemen haben die Rentner-Pools jedenfalls nicht zu kämpfen. Mehr als 20 Millionen Ruheständler leben schon jetzt in der Bundesrepublik. Und es werden immer mehr - auch mit staatlicher Unterstützung [...]. (http://www.spiegel.de/spiegel, dostęp: 20 lipca 2015)

W sensie globalnym tekst odnosi się do sytuacji na niemieckim rynku pracy w 2006 roku i opisuje ideę ponownego zatrudniania seniorów. Idea sięgania po wiedzę fachową emerytowanych pracowników jest spowodowana trudną sytuacją demograficzną (brak młodych kadr) i trudną sytuacją ekonomiczną niemieckich firm (kryzys finansowy w Europie). Pojęcie globalne manifestuje się na płaszczyźnie językowej przez grę językową wprowadzoną w tytule tekstu i opartą na związku frazeologicznym grauer Markt (szary rysunek). Wyrażenie pierwotnie występujące na gruncie ekonomii na oznaczenie nielegalnej działalności gospodarczej i niosące ze sobą negatywne konotacje zostaje użyte na określenie stowarzyszeń zrzeszających seniorów aktywnych zawodowo (Senior Experten Service - SES). Deleksykalizacji ulega w tym kontekście słowo grau (szary), które zostaje użyte w swym pierwotnym znaczeniu koloru i odnosi się w tym przypadku do siwych włosów seniorów. Za sprawą tak sformułowanego tytułu autor tekstu prezentuje częściowo ekspercki punkt widzenia, częściowo punkt widzenia komentatora i w ironiczny sposób wypowiada się na temat polityki państwa oraz działań podejmowanych przez ówczesnego ministra pracy Franza Münteferinga. Na tak rozumiane 
pojęcie globalne składają się liczne pojęcia częściowe, których interpretacja wymaga powiązania $\mathrm{z}$ kontekstem, a także uruchomienia dodatkowej wiedzy przez tłumacza.

Do zadań organizacji Senior Experten Service (SES) należy zrzeszanie seniorów ekspertów i wysyłanie ich jako wolontariuszy na cały świat do firm przeżywających trudności finansowe. Ich praca polega na doradzaniu przedsiębiorcom w prowadzaniu firmy i w sprawach finansowych. W tym kontekście autor określa seniorów jako graue Stars - jest to kontynuacja gry językowej z tytułu tekstu i nawiązanie do niemieckiego serialu telewizyjnego Der große Bellheim, w którym seniorzy ratują przedsiębiorstwo przed bankructwem. W odniesieniu do pracy seniorów autor używa obrazowej konstrukcji Banken beschwören, która oznacza 'zaklinać, błagalnie, usilnie o coś prosić' (SI PONS).

Idea związków Senior Experten Service stopniowo rozszerza się w całych Niemczech. Z pomocy seniorów korzystają małe firmy, początkujący przedsiębiorcy, a nawet koncerny. Specyfikę tej formy zatrudnienia oddają w tekście złożenia rzeczownikowe, np. złożenia okazjonalne z rzeczownikiem Einsatz, jak choćby Rentner-Einsätze, oraz złożenie Rentner-Pools. Okazjonalny charakter konceptualizacji Rentner-Einsätze wynika z niekonwencjonalnego pod względem semantycznym zestawienia rzeczownika Rentner z rzeczownikiem Einsatz. Celem połączenia z rzeczownikiem Einsatz, który oznacza 'akcję, operację, interwencję, np. policji lub wojska' zwykle w sytuacji zagrożenia (SI PONS), jest wyprofilowanie interwencyjnego i krótkotrwałego charakteru współpracy między przedsiębiorcami a seniorami w celu zażegnania sytuacji kryzysowej na rynku pracy. W rezultacie emerytowani pracownicy są konceptualizowani jako ci, którzy podejmują się misji ratowania przedsiębiorstw znajdujących się w trudnej sytuacji kadrowej lub ekonomicznej. Złożenie Rentner-Pools bazuje na terminie stricte ekonomicznym z języka angielskiego 'pul', który oznacza 'konsorcjum lub krótkotrwałe porozumienie przedsiębiorców zawierane $\mathrm{w}$ celu realizowania konkretnych przedsięwzięć lub w okresach słabej koniunktury' (SJP PWN). W tym przypadku chodzi o specyficzny rodzaj konsorcjum zawieranego między koncernami a zakładanymi przez nie spółkami zależnymi, w których zatrudniani są byli pracownicy. Do pełnego zrozumienia tego złożenia potrzebna jest znajomość znaczenia części składowych, a także dodatkowa wiedza ekonomiczna o funkcjonowaniu tego rodzaju podmiotów. Związki SES i konsorcja zrzeszające seniorów nie muszą obawiać się braku pracowników. Tę informację autor realizuje w tekście w niekonwencjonalny sposób, używając rzeczownika Nachwuchs 'narybek, młoda kadra' (SI PONS) oraz złożenia Nachwuchsprobleme. Rzeczownik Nachwuchs odnosi się więc w tym kontekście paradoksalnie 
i trochę ironicznie nie tyle do ludzi młodych, co do stale powiększającej się grupy seniorów w Niemczech. Seniorzy tworzą swego rodzaju wtórny rynek w stosunku do zwykłego rynku pracy.

Dla semantyki tekstu ważny jest także sposób konceptualizowania wiedzy seniorów, co możemy obserwować w następującym zdaniu „Immer mehr Personalchefs würden erkennen, dass mit Rentner-Einsätzen vorhandenes Know-how rasch, günstig und vor allem flexibel eingekauft werden könne". U podstaw tej konstrukcji w planie pojęciowym leży metafora konceptualna, którą na potrzeby tej analizy określam jako WIEDZA FACHOWA TO PRODUKT. Dochodzi w tym przypadku do rzutowania pojęciowego między domeną transakcji handlowej (domena źródłowa) a domeną pracy zawodowej (domena docelowa). Rezultatem takiej operacji pojęciowej jest konceptualizowanie wiedzy specjalistycznej seniorów jako obiektu transakcji handlowej, na co wskazuje użycie czasownika einkaufen.

W kontekście całego tekstu i z punktu widzenia przekładu istotny jest również sposób konceptualizowania wieku, manifestujący się w takich leksemach jak rüstige Rentner i w potocznie stosowanym idiomie zum alten Eisen gehören, który oznacza bycie przestarzałym ${ }^{4}$.

\section{Tekst prasowy pt. Grauer Markt w przekładach na język polski - analiza kognitywna rozwiązań translatorskich}

Dalsze rozważania koncentrują się na prześledzeniu procesu decyzyjnego początkujących tłumaczy i na analizie zaproponowanych przez nich rozwiązań translatorskich dla wybranych konstrukcji językowych pod kątem ich ekwiwalencji znaczeniowej z tekstem wyjściowym. Analiza rozwiązań translatorskich obejmuje omówienie zarówno ekwiwalentów dosłownych, jak i funkcjonalnych, a także wyjaśnienie najczęściej popełnianych błędów semantycznych. Pierwsze różnice w sposobie konstruowania wyrażeń złożonych w języku polskim i niemieckim i zarazem pierwsze trudności w przekładzie możemy obserwować już w tytule tekstu oraz w pozostałych związkach wyrazowych z przymiotnikiem grau.

${ }^{4}$ W niniejszym artykule koncentruję się na aspektach dydaktycznych. Na temat potencjału semantycznego złożeń i związków frazeologicznych na podstawie założeń kognitywnej teorii języka w tekście i w przekładzie również w: M. Filar (2016) w artykule pt. Złożenia i związki frazeologiczne $w$ tekście $i$ w przekładzie - implikacje dla dydaktyki przekładu, [w:] „Lingwistyka Stosowana" 2016, nr 16, z. 2016, s. 11-22. 
(1) Grauer Markt (1a) *Szara strefa

(1b) ${ }^{\star}$ Szary rynek

(1c) Siwy rynek

(1d) Rynek pracy otwarty dla seniorów

Zasadniczą trudność $\mathrm{w}$ przekładzie stanowi w tym przypadku oddanie gry językowej w tytule tego tekstu oraz znalezienie trafnego ekwiwalentu dla konstrukcji z przymiotnikiem grau. Próba przetłumaczenia wyrażenia Grauer Markt za pomocą podobnego związku frazeologicznego w języku polskim w przykładzie (1a) pozwala na oddanie tylko części znaczenia związanej z prowadzeniem nielegalnej działalności gospodarczej i towarzyszącej mu negatywnej konotacji, nie prowadzi jednak do przekazania zasadniczej treści tekstu, tj. pewnej tendencji na rynku pracy związanej z ponownym zatrudnianiem seniorów przez firmy. Również konstrukcja składniowa Szary rynek w przykładzie (1b) nie spełnia tej funkcji komunikacyjnej, ponieważ przymiotnik szary nie implikuje żadnego odniesienia do seniorów. Pewną alternatywą dla przymiotnika szary może być w tym kontekście przymiotnik siwy, używany w języku polskim głównie w odniesieniu do koloru włosów. Wyrażenie Siwy rynek, choć niekonwencjonalne, może odnosić się do fizycznych oznak starzenia, a przez to pośrednio również do seniorów i w ten sposób do treści całego tekstu. Dużo trafniejszym ekwiwalentem spośród proponowanych rozwiązań jest jednak równoważnik zdania Rynek pracy otwarty dla seniorów. Przywołuje on explicite pojęcie rynku pracy, pojęcie seniora i sygnalizuje zachodzącą między nimi relację za pomocą wyrażenia imiesłowowego otwarty na. Mamy więc w tym przypadku do czynienia z uszczegółowieniem konceptualizowanej sceny, a w szerszym kontekście także z wyjaśnieniem treści tytułu dla polskiego odbiorcy. Innym, bardziej kreatywnym rozwiązaniem, mogłoby być w tym przypadku zbudowanie gry językowej na odniesieniu do innego obszaru wiedzy, na przykład do domeny nieruchomości i zaproponowanie jako ekwiwalentu wyrażenia Rynek wtórny, które właśnie w tym kontekście i za sprawą przymiotnika wtórny może odnosić się do ponownego zatrudniania seniorów.

Podobne trudności możemy obserwować również w tłumaczeniu pozostałych konstrukcji składniowych z przymiotnikiem grau, takich jak graue Stars czy graumelierte Kunden, np.

(2) Wie im TV-Hit „Der große Bellheim” waren es graue Stars, die das Unternehmen schließlich retteten.

(2a) Podobnie jak w telewizyjnym hicie „Der große Bellheim” siwe gwiazdy uratowały przedsiębiorstwo. 
(2b) Podobnie jak w telewizyjnym hicie „Der große Bellheim”, gwiazdami byli również seniorzy / emerytowani pracownicy, ratujący ostatecznie przedsiębiorstwo.

(2c) I tak jak w znanym niemieckim serialu „Der große Bellheim”, seniorzy stali się superbohaterami, którzy ostatecznie uratowali firmę.

Analiza zaproponowanych ekwiwalentów dla wyrażenia graue Stars pozwala zauważyć, że tłumaczenie dosłowne w przykładzie (2a) jest wprawdzie poprawne pod względem gramatycznym i znaczeniowym, ale równocześnie trudno akceptowalne $\mathrm{w}$ języku polskim. Znaczenie trafniejszymi i bardziej czytelnymi odpowiednikami dla polskiego odbiorcy są w tym przypadku ekwiwalenty funkcjonalne, takie jak seniorzy czy emerytowani pracownicy w przykładzie (2b), przywołujące zamiast domeny koloru domenę związaną $\mathrm{z}$ wiekiem. Ciekawym odpowiednikiem nawiązującym również do niemieckiego oryginału jest także określenie seniorów jako superbohaterów w przykładzie (2c), aktywujące równocześnie domenę związaną z wiekiem i domenę filmu, również przywoływaną w oryginale.

Kolejne zadanie translatorskie polegało na znalezieniu właściwego ekwiwalentu dla konstrukcji bazującej na wieloznacznym w języku niemieckim czasowniku beschwören.

(3) Unterstützt von zwei weiteren SES-Männern [...], half er beim Ausfüllen von Formularen, suchte den Kontakt zum Insolvenzverwalter, beschwor die Banken und telefonierte mit Auftraggebern.

(3a) Wspierany przez dwóch wolontariuszy SES [...] pomagał przy wypełnianiu formularzy, szukał kontaktu z syndykiem, ${ }^{\star}$ zaskarży1 banki i rozmawiał ze zleceniodawcami.

(3b) Wspierany przez dwóch specjalistów z SES [...] pomagał przy wypełnianiu formularzy, szukał kontaktu z syndykiem, ${ }^{\star}$ zaprzysiegał banki i rozmawiał ze zleceniodawcami.

(3c) Wspierany przez dwóch członków SES [...] pomagał przy wypełnianiu formularzy, szukał kontaktu z syndykiem, negocjował z bankami i rozmawiał ze zleceniodawcami.

Pierwsze dwie propozycje tłumaczenia tej konstrukcji w punkcie (3a) i (3b) wskazują na poważne błędy interpretacyjne i świadczą o niezrozumieniu tego fragmentu tekstu. W przykładzie (3a) przyczyną błędu jest mylne utożsamienie czasownika beschwören z podobnym pod względem ortogra- 
ficznym i fonetycznym czasownikiem beschweren, który może oznaczać „obciążać winą” lub w wariancie zwrotnym „skarżyć się na coś lub kogoś”. Z kolei w przykładzie (3b) mamy do czynienia z mylnym odczytaniem znaczenia czasownika beschwören $\mathrm{z}$ kontekstu i w rezultacie z błędnym wyborem wariantu znaczeniowego (por. SI PONS). Z poprawnym ekwiwalentem mamy do czynienia dopiero w przykładzie (3c). Czasownik beschwören występujący $\mathrm{w}$ oryginale $\mathrm{w}$ znaczeniu 'zaklinać, prosić' (por. SI PONS) zostaje zastąpiony czasownikiem negocjować, który aktywuje domeny związane z komunikacją i prowadzeniem firmy. W kontekście rozmów z bankami jego użycie jest trafne.

Sięgnięcie do słownika jednojęzycznego, wyjaśniającego znaczenie tego czasownika przez parafrazę „durch einen Schwur bekräftigen” (DWDS) pozwoliłoby na dokładniejsze określenie jego znaczenia i znalezienie ekwiwalentów również w języku bardziej formalnym.

Kolejne zadanie translatorskie polegało na znalezieniu właściwego ekwiwalentu w języku polskim dla złożeń z rzeczownikiem Einsatz/Einsätze-, które ze względu na swoją okazjonalność wymagały nie tylko dokładnej analizy znaczenia, ale także pewnej kreatywności językowej w przekładzie.

(4) Solche Rentner-Einsätze machen Schule.

(4a) *Takie akcje-emerytów znajdują naśladowców.

(4b) Taka forma angażowania seniorów znajduje coraz większą liczbę naśladowców.

Próba oddania tego złożenia za pomocą analogicznych okazjonalizmów i dosłownych ekwiwalentów w języku polskim takich jak akcje-seniorów (z zachowaniem oryginalnej pisowni) lub operacje seniorów jest błędna, ponieważ nie uwzględnia kontekstu wypowiedzi (może także świadczyć o słabej znajomości języka rodzimego przez osobę tłumaczącą). Bardziej adekwatnym odpowiednikiem wyrażenia Rentner-Einsätze jest w tym kontekście konstrukcja taka forma angażowania seniorów, bazująca na znaczeniu czasownika angażować, tj. 'przyjmować do pracy, włączać kogoś w jakąś działalność, jakieś sprawy' (SJP PWN), i wyjaśniająca także znaczenie tego okazjonalizmu. Tego rodzaju tłumaczenie generalizujące pozwala na równoczesne odniesienie się zarówno do działalności seniorów prowadzonej w ramach wolontariatu, jak i do działalności zarobkowej. Kreatywność językowa tłumacza przejawia się w tym przypadku w oddaniu liczby mnogiej rzeczownika Einsatz, która w polskim tekście zostaje wyrażona nietypowo - na płaszczyźnie leksykalnej za pomocą wyrażenia taka forma i przez rzeczownik odczasownikowy o zna- 
czeniu iteratywnym angażowanie, który implikuje powtarzalność czynności.

Również w przypadku innych złożeń okazjonalnych z rzeczownikiem Einsatz/Einsätze konieczny jest wybór ekwiwalentu uwzględniającego kontekst wypowiedzi.

(5) Bosch, Siemens oder der deutsche Ableger des Pharmakonzerns Pfizer etwa engagieren ihre eigenen Ex-Mitarbeiter für dann allerdings gutbezahlte Kurzeinsätze.

(5a) ${ }^{*}$ Bosch, Siemens czy niemiecka filia koncernu farmaceutycznego Pfizer angażują swoich ex-pracowników do krótkich ale dobrze płatnych akcji/operacji.

(5b) Bosch, Siemens czy niemiecka filia koncernu farmaceutycznego Pfizer angażują swoich byłych pracowników do krótkich ale dobrze płatnych zleceń/zadań.

Ekwiwalenty w zdaniu (5a) również w tym przypadku nie oddają właściwego znaczenia złożenia. Uszczegółowienie złożenia przez imiesłów bierny gutbezahlte Kurzeinsätze w niemieckim tekście wyjściowym wymaga również uszczegółowienia w przekładzie, dlatego bardziej trafnymi ekwiwalentami w języku polskim są w tym kontekście wyrażenia dobrze płatne zlecenia lub dobrze płatne zadania, projekty, a także krótkoterminowe umowy o prace.

Następne zadanie translatorskie polegało na przetłumaczeniu dwóch złożeń rzeczownikowych Rentner-Pools i Nachwuchsprobleme, co wymagało od tłumacza nie tylko dokładnej analizy ich części składowych, ale także uruchomienia dodatkowej wiedzy dla prawidłowego oddania ich znaczenia w języku polskim.

(6) Mit Nachwuchsproblemen haben die Rentner-Pools jedenfalls nicht zu kämpfen. Mehr als 20 Millionen Ruheständler leben schon jetzt in der Bundesrepublik. Und es werden immer mehr auch mit staatlicher Unterstützung.

(6a) ${ }^{\star}$ Stowarzyszenia seniorów nie muszą walczyć ${ }^{*}$ z problemami młodego pokolenia. W Republice Federalnej Niemiec żyje obecnie ponad 20 milionów emerytowanych pracowników. I będzie ich jeszcze więcej - również ze wsparciem ze strony państwa.

(6b) ${ }^{\star}$ Seniorzy nie muszą konkurować ${ }^{\star} \underline{z}$ młodą kadrą. W Republice Federalnej Niemiec jest ich już ponad 20 milionów. A dzięki wsparciu państwa będzie ich jeszcze więcej. 
(6c) Pule emerytów nie muszą walczyć z problemem braku pracowników. Obecnie w Niemczech jest już ponad 20 milionów seniorów, a dzięki wsparciu państwa będzie ich coraz więcej.

(6d) Koncerny zatrudniające byłych pracowników w swoich filiach nie muszą martwić się o brak pracowników. Obecnie w Niemczech jest już ponad 20 milionów seniorów, a dzięki wsparciu państwa będzie ich coraz więcej.

Złożenie rzeczownikowe Rentner-Pools wymaga od tłumacza uruchomienia wiedzy z zakresu ekonomii, ponieważ jego człon główny stanowi termin ekonomiczny z języka angielskiego. Dla poprawnego tłumaczenia tego złożenia istotne jest zrozumienie, że samo oddanie terminu w języku polskim jest niewystarczające i że potrzebne jest doprecyzowanie, na czym polega tego rodzaju współpraca z seniorami. Użycie w tym kontekście rzeczownika stowarzyszenia w języku polskim jest błędne, bo wskazuje na inny rodzaj współpracy. Termin ten profiluje głównie idee zrzeszania ludzi o wspólnych zainteresowaniach w celach niezarobkowych. Również próba tłumaczenia zaproponowana w przykładzie (6b) nie jest do końca zgodna $\mathrm{z}$ treścią złożenia $\mathrm{w}$ tekście wyjściowym, dlatego że kładzie nacisk tylko na wierne oddanie terminu ekonomicznego i nie uwzględnia kontekstu jego użycia. Wskutek tego zaproponowany ekwiwalent staje się mało czytelny dla polskiego odbiorcy. Najlepszym odpowiednikiem dla złożenia Rentner-Pools spośród analizowanych przykładów jest tłumaczenie wyjaśniające Koncerny zatrudniajace byłych pracowników $w$ swoich filiach w przykładzie (6c), aktywujące równocześnie domenę pracy zawodowej oraz domenę ekonomii.

Równie ciekawym przykładem jest złożenie Nachwuchsprobleme, które zmienia swoje znaczenie pod wpływem kontekstu i którego przekład wymaga od tłumacza odniesienia do aktualnej sytuacji na niemieckim rynku pracy. Analiza rozwiązań translatorskich wskazuje, że główny błąd w tłumaczeniu polegał tu na zbyt dużej dosłowności i niedoprecyzowaniu relacji między członami złożenia. Błędem jest tłumaczenie tylko części składowych tego złożenia, bez odniesienia się do szerszego kontekstu, tj. trudnej sytuacji na niemieckim rynku pracy. Nie chodzi w tym przypadku o problemy młodej kadry, ani o konkurencję między młodą a starą kadrą, jak to mogą sugerować przekłady (6a) i (6b), lecz o kłopoty wynikające z braku młodych pracowników. Mylące może się okazać również tłumaczenie rzeczownika Nachwuchs jako młodej kadry, gdyż w tym kontekście odnosi się on nie do ludzi młodych, lecz do aktywnych zawodowo seniorów. Poprawne tłumaczenie tego złożenia na język polski wy- 
maga zwerbalizowania obu płaszczyzn znaczeniowych, jak w przykładzie (6c).

Następne zadanie translatorskie polegało na odtworzeniu sposobu konstruowania treści w zdaniu, które bazuje na metaforze pojęciowej WIEDZA FACHOWA TO PRODUKT.

(7) Immer mehr Personalchefs würden erkennen, dass mit Rentner-Einsätzen vorhandenes Know-how rasch, günstig und vor allem flexibel eingekauft werden könne.

(7a) Coraz więcej dyrektorów personalnych zauważa, że wiedza specjalistyczna emerytów jest produktem, który można kupić/nabyć w szybki, korzystny i elastyczny sposób.

(7b) *Coraz więcej dyrektorów personalnych zauważa, że dzięki umowom dla byłych pracowników wiedza fachowa sprzedaje się szybko, korzystnie i elastycznie.

Analiza powyższych rozwiązań translatorskich pozwala zauważyć, że oba ekwiwalenty trafnie oddają treść pojęciową tego zdania, różni je natomiast sposób jej konstruowania. Sposób konstruowania treści w tym zdaniu ma istotne znaczenie dla całego tekstu, bo oddaje nietypową sytuację na rynku pracy, sytuującą dyrektorów firmy w funkcji kupujących wiedzę specjalistyczną, a seniorów w funkcji sprzedających swoje kompetencje. Taki sposób konstruowania sceny, wyrażony w oryginale za pomocą czasownika einkaufen, udało się zachować w przekładzie na język polski przez użycie dosłownych odpowiedników, a więc czasownika kupować lub jego bardziej formalnego wariantu nabywać. Podobnie jak czasownik einkaufen, czasowniki kupować i nabywać aktywują w język polskim domenę transakcji handlowej i profilują dyrektorów firm w funkcji kupujących. Użycie w tym samym kontekście czasownika sprzedawać aktywuje wprawdzie tę samą domenę konceptualną, ale prowadzi równocześnie do zmiany sposobu perspektywizacji w przekładzie i profiluje dyrektorów firm jako sprzedających wiedzę seniorów.

Ostatnie zadanie translatorskie polegało na znalezieniu odpowiednika w języku polskim dla idiomu zum alten Eisen gehören, który w języku potocznym profiluje stan bycia przestarzałym i niepotrzebnym, a w analizowanym tekście odnosi się do seniorów.

(8) In Suzhou gehört Weinmann dennoch zum alten Eisen.

(8a) *W Suzhou Weinmann odchodzi już jednak do lamusa.

(8b) W Suzhou Weinmann nadaje się już na złom. 
Ekwiwalent słownikowy odchodzić do lamusa przywołuje wprawdzie zamierzone $\mathrm{w}$ tekście wyjściowym znaczenie bycia starym i niepotrzebnym, jest jednak używany w języku polskim w odniesieniu do obiektów nieożywionych, zwyczajów, a nie w odniesieniu do ludzi. Dlatego trafniejszym rozwiązaniem w tym kontekście jest wyrażenie nadawać się na złom (por. SI PONS) w (8b). Wyrażenie to nawiązuje zarówno w płaszczyźnie znaczeniowej das alte Eisen (żelazo)/złom, jak i w rejestrze stylistycznym do użytego w tekście wyjściowym idiomu i jest stosowane w języku polskim w odniesieniu do ludzi i do rzeczy.

\section{Wnioski dla dydaktyki przekładu}

Wracając do postawionego we wstępie pytania, która $\mathrm{z}$ prezentowanych $\mathrm{w}$ ramach językoznawstwa kognitywnego koncepcji badawczych może stać się skutecznym i zarazem najbardziej przystępnym narzędziem w kształceniu umiejętności kreatywnego rozumienia początkujących tłumaczy, chciałabym przedstawić kilka argumentów przemawiających za przydatnością gramatyki kognitywnej Langackera w dydaktyce przekładu.

Zaletą zaproponowanego modelu analizy tekstu jest to, że bazuje on na jednej spójnej koncepcji badawczej, w prosty sposób ukazuje złożoność procesu interpretacji tekstu i może zostać wykorzystany jako narzędzie zarówno interpretacji tekstu, jak i oceny przekładu. Zastosowanie modelu umożliwia nauczycielowi śledzenie procesów konceptualizacji i rekonceptualizacji początkujących tłumaczy oraz $\mathrm{w}$ razie potrzeby ingerowanie $\mathrm{w}$ ten proces. Wprowadzenie rozróżnienia na pojęcia globalne i szczegółowe pozwala w prosty sposób wykształcić u początkujących tłumaczy umiejętności określania makro- i mikrostrategii w tłumaczeniu i może być pomocne w ustalaniu hierarchii ważności elementów w przekładzie. Wykorzystanie w modelu dynamicznej i encyklopedycznej koncepcji znaczenia uczy uważności na kontekst i modyfikacje kontekstowe znaczenia jednostek leksykalnych, a także zwraca uwagę nie tylko na treści pojęciowe, ale i na sposób ich konstruowania w tekście. Podstawy gramatyki kognitywnej umożliwiają również precyzyjną ocenę proponowanych ekwiwalentów i szczegółowe wyjaśnienie różnych błędów interpretacyjnych w przekładzie.

Z perspektywy uczącego się model kładzie nacisk przede wszystkim na rozwijanie sprawności wnikliwego rozumienia tekstu już na etapie przygotowania do tłumaczenia, a następnie uczy kreatywnego myślenia językowego w trakcie samego tłumaczenia, które polega czasami na konieczności odnie- 
sienia się do innych elementów lub rodzajów wiedzy niż oryginał, by ostatecznie oddać znaczenie zamierzone w tekście wyjściowym, jak w przypadku wyrażeń Grauer Markt i Rynek Wtórny, lub na poszukiwaniu ekwiwalencji na innej płaszczyźnie języka niż w oryginale, jak w przypadku rzeczownika Einsatz/Einsätze.

Przedstawiony $\mathrm{w}$ artykule model analizy tekstu powstał z myślą o początkujących tłumaczach, którzy nie mają jeszcze większego doświadczenia w zakresie translacji, i może znaleźć zastosowanie głównie w dydaktyce tekstów użytkowych, zarówno w ramach zajęć o charakterze warsztatowym, jak i w indywidualnej praktyce translacyjnej.

\section{Literatura}

De, Bono, E., 1971, Laterales Denken. Ein Kursus zur Erschließung Ihrer Kreativitätsreserven [Lateral Thinking. A Textbook of Creativity], tłum. M. Carroux, W. Eisermann, Reinbek bei Hamburg.

Filar, M., 2016, „Złożenia i związki frazeologiczne w tekście i w przekładzie implikacje dla dydaktyki przekładu", [w:] Lingwistyka Stosowana, nr 16, s. 11-22, 7 lutego 2016, URL:http://www.ls.uw.edu.pl/documents/72767 21/13368455/2+Lingwistyka+Stosowana+16+Magdalena+Filar.pdf

Fillmore, Ch.J., 1977, „Scenes-and-frames semantics”, [w:] Linguistic structures processing, A. Zampolli (red.), Amsterdam, s. 55-88.

Grice, H.P., 1975, "Logic and conversation", [w:] Syntax and semantics. Vol. 3. Speech acts, P. Cole, J.L. Morgan (red.), New York.

Grucza, F., 1999, „Translacja a kreatywność”, [w:] Lingua Legis, nr 7, s. 2-4.

Hejwowski, K., 2004, Komunikacyjno-kognitywna teoria przekładu, Warszawa. Kubaszczyk, J., 2000, „Kognition und Übersetzen. Über das Übersetzen von Konzepten", [w:] Glottodidactica XXVII, L. Zabrocki, (red.), s. 77-89.

Kussmaul, P., 1997, „Die Rolle der Psycholinguistik und der Kreativitätsforschung bei der Untersuchung des Übersetzungsprozesses", [w:] Translationsdidaktik. Grundfragen der Übersetzungswissenschaft, E. Fleischmann, W. Kutz, P.A. Schmitt (red.), Tübingen, s. 605-611.

Kussmaul, P., 2007, Kreatives Übersetzen, Tübingen.

Lakoff, G., Johnson, M., 1980, Metaphors we live by, Chicago.

Lakoff, G., 1987, Women, Fire and Dangerous Things. What Categories Reveal about the Mind, Chicago.

Lakoff, G., Turner, M. 1989, More than cool reason - A field guide to poetic metaphor, Chicago. 
Langacker, R., 2005, Wykłady z gramatyki kognitywnej, tłum. A. Głaz, K. Wengorek-Dolecka, Lublin.

Langacker, R., 2009, Gramatyka kognitywna. Wprowadzenie, tłum. zbior., Kraków.

Małgorzewicz, A., 2012, Die Kompetenzen des Translators aus kognitiver und translationsdidaktischer Sicht, Wrocław.

Małgorzewicz, A., 2013, „Translationsrelevante Wissensarten, kognitionsunterstützende Kompetenzen und Eigenschaften des Translators im Prozess der Bedeutungskonstruktion", [w:] Sprache - Literatur - Kultur Im Germanistischen Gefüge. Sprachwissenschaft im Fokus germanistischer Forschung und Lehre, E. Błachut, J. Jarosz i in. (red.), Wrocław-Dresden, s. 293-307.

Małgorzewicz, A., 2014, „Językowe i niejęzykowe kompetencje tłumacza. Próba zdefiniowania celów translodydaktyki akademickiej", [w:] Lingwistyka Stosowana, nr 11, s. 1-10, 29 sierpnia 2015, https://portal.uw.edu. $\mathrm{pl} /$ documents/7276721/12447778/Lingwistyka+Stosowana+11+Anna+ Malgorzewicz.pdf.

Schank, R., 1982a, Dynamic memory. A theory of reminding and learning in computers and people, Cambridge.

Schank, R., 1982b, Reading and understanding: Teaching from the perspective of artificial intelligence, Hillsdale.

Schank, R., Abelson, R., 1977, Scripts, plans, goals and understanding. An inquiry in human knowledge structures, Hillsdale.

Tabakowska, E., [1993] 2001, Językoznawstwo kognitywne a poetka przekła$d u$ [Cognitive Linguistics and Poetics of Translation], tłum. A. Pokojska, Kraków.

Vannerem, M., Snell-Hornby M., 1986, „Die Szene hinter dem Text: ,scenes-and-frames- semantics' in der Übersetzung", [w:] Übersetzungswissenschaft - Eine Neuorientierung zur Integrierung von Theorie und Praxis, M. Schnell-Hornby (red.), Tübingen, s. 194-205.

Vermeer, H.J., Witte H., 1990, Mögen Sie Zistrosen? Scenes \& frames \& channel im translatorischen Handeln, Heidelberg.

Wills, W., 1988, Kognition und Übersetzen. Zu Theorie und Praxis der menschlichen und maschinellen Übersetzung, Tübingen.

Żmudzki, J., 2013, „Holizm funkcjonalny w perspektywie translatoryki antropocentrycznej", [w:] Lingwistyka Stosowana, nr 8, s. 177-187.

\section{Źródła internetowe}

Ramspeck, S., 2006, „Grauer Markt”, [w:] Der Spiegel, nr 32, http://www.spiegel.de/spiegel/ (dostęp: 20 lipca 2015). 
DWDS - Das Digitale Wörterbuch der deutschen Sprache, http://www.dwds. de/, (dostęp: 22 sierpnia 2015).

SJP PWN - Słownik Języka Polskiego PWN, http://sjp.pwn.pl/, (dostęp: 22 sierpnia 2015).

SI PONS - Słownik Internetowy PONS, http://pl.pons.com, (dostęp: 22 sierpnia 2015).

\section{Cognitive model of text analysis in the didactics of translation - training the skill of creative comprehension}

\section{Summary}

The author attempts to apply cognitive linguistics to the didactics of translation, and shows how to train a skill fundamental for every translation: the skill of creative comprehension. To do this within the framework of Langacker's cognitive grammar, the author presents a simplified model of the analysis of a source text with its translation in mind, analyses a German press article, and proves the applicability of the model at the stage of the analysis of translation equivalents proposed by beginner translators. The comparative analysis of unacceptable, acceptable and very good translation solutions puts an emphasis on the analysis of the process of translation, and introduces into it an element of self-reflection. The analysis of translation solutions shows that the most common errors are those resulting from being too literal in translation, and that a correct, understandable translation often requires the translator to be creative. This creativity consists in activating other knowledge components, or in searching for equivalents on other language planes. The source text is a German press article entitled Grauer Markt and its translations into Polish were performed by MA students of German.

Keywords: cognitive model of text analysis, creative comprehension, written translation, translation errors, self-reflection 